\title{
Publication rate of abstracts on breast cancer presented at different scientific events in Brazil
}

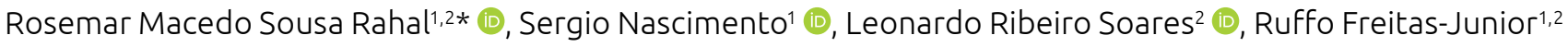

\section{ABSTRACT}

Introduction: Medical congresses allow scientific production to be appropriately disseminated and discussed. However, most of the scientific papers presented at medical congresses do not go on to be published in indexed journals. The present study aimed to characterize the abstracts presented at three different congresses on breast cancer held in Brazil, and to determine the publication rate of these three events. Methods: Observational, retrospective study, where the observation unit consisted of the scientific papers presented at the Brazilian Congress of Mastology (CBM), Jornada Paulista de Mastologia (JPM) and Brazilian Breast Cancer Symposium (BBCS) in 2017. Initially, we recorded all the abstracts of works presented at the event. Subsequently, the works were searched in digital databases (BIREME/LILACS and MEDLINE/PubMed) and in the respective resumes of the authors on the Lattes platform. Results: The study included 266 abstracts of scientific papers presented in the three selected events, of which 21 (7.9\%) were published in an indexed journal. Most of these studies were conducted predominantly in public institutions (71.1\%), located in the State of São Paulo (30.5\%) and were presented in the form of a poster (77.8\%). The publication rate from the BBCS, CBM and JPM was $13.4,5.4$ and $3.4 \%$, respectively ( $p=0.03$ ). Considering the published articles, there was no difference in journal impact factor between the congresses ( $p=0.49$ ). "Mastology" was the journal that received the largest number of publications ( $n=8$; 38.1\%). Conclusion: In 2017, less than $10 \%$ of the abstracts on breast cancer presented at Brazilian congresses were published in an indexed journal. Among the main specialty events in the country, the Brazilian Breast Cancer Symposium has a significantly higher publication rate.

KEYWORDS: breast neoplasms; bibliometrics; research report; journal article.

\section{INTRODUCTION}

The dissemination of knowledge obtained through scientific research is a primary step in the evolution process of health care ${ }^{1,2}$. Accordingly, congresses and scientific events are the opportune place for the presentation and discussion of new knowledge, where the authors of each study can present their results and the practical implications of the research, among other benefits. In addition, medical congresses allow continuing education, the discussion of clinical cases and interpersonal contact between different geographic regions ${ }^{3,4}$.

After the production of knowledge and the presentation of results at scientific events, it is essential that this content be published in some safe and reliable source of accessible information. This publication allows the globalization of knowledge and external validation of results, and it has different implications for clinical practice ${ }^{1,2}$. Nevertheless, it must occur in indexed journals, with an experienced editorial board and rigorous peer review ${ }^{2,5}$.

In recent years, despite the expansion of scientific production worldwide, it is observed that most scientific papers presented in medical congresses are not published later in indexed journals ${ }^{6,7}$. In Brazil, most bibliometric studies indicate a publication rate between 5 and $20 \%$ of the research presented at medical congresses ${ }^{6,7}$. At the University of São Paulo, one of the most prestigious universities in Latin America, less

${ }^{1}$ Faculdade de Medicina, Universidade Federal de Goiás - Goiânia (GO), Brasil.

${ }^{2}$ Centro Avançado de Diagnóstico da Mama, Hospital das Clínicas, Universidade Federal de Goiás - Goiânia (GO), Brasil.

*Corresponding author: rosems@terra.com.br

Conflict of interests: nothing to declare.

Received on: 07/23/2020. Accepted on: 08/24/2020. 
than $50 \%$ of the doctoral theses presented between 1990 and 2000 were published within five years ${ }^{8}$. Together, these data raise questions about the model of scientific production in Brazil and reinforce the hypothesis that the rate of publication of papers presented at mastology congresses is modest.

In Brazil, the first bibliometric evaluation studies related to mastology were recently published, but they are limited to scientific production in oncoplastic surgery and breast repair surgery ${ }^{9,10}$. However, to our knowledge, no study has been carried out to assess the scientific production presented at the mastology congresses held in the country and the articles resulting from these presentations.

Our aim was to characterize the studies presented at three different mastology congresses held in Brazil, and to evaluate the publication rate of these events.

\section{METHODS}

This was an observational, retrospective study, where the observation unit consisted of the scientific papers presented at three different events in mastology: Brazilian Congress of Mastology (CBM), Jornada Paulista de Mastologia (JPM) and Brazilian Breast Cancer Symposium (BBCS). The first two prioritize continuing education and have a parallel agenda dedicated to scientific work ${ }^{11}$. BBCS is directed at scientific research and offers several facilities for speakers and high prizes for the best papers presented ${ }^{12}$. The events were selected for their importance in the context of mastology in Brazil. The year 2017 was selected taking into account an opportune period of two years for the publication of free themes presented in the respective congresses. ${ }^{13}$.

\section{Variables}

Initially, all works presented at the aforementioned congresses were selected in the respective abstract books and included in a specific database, with the aid of the Microsoft Excel program (Microsoft, USA), version 2013. The following information was collected: title of the abstract, authors, institution and state where the study was conducted. The free themes were classified according to the type of presentation: poster, oral presentation and, when relevant, comment poster.

The main theme of the study was classified as "epidemiology", "breast cancer diagnosis", "breast cancer treatment”, "breast cancer rehabilitation", "benign pathologies", "in situ carcinoma”, "experimental studies" and "miscellaneous themes". The category "diverse themes" included studies not classified in the others, such as "breast cancer during pregnancy" and "access to health services", among others. The places where the studies were carried out were classified as "public services", "private services" or "mixed".
To assess the possible publication, the works were initially sought in the description of the personal curriculum vitae available on the Lattes Platform (www.lattes.cnpq.br), of the National Council for Scientific and Technological Development (CNPq). The search was carried out independently by two researchers, using the names of the authors of each abstracted presented at the congress.

Subsequently, the studies were searched in the online databases Latin American and Caribbean Health Sciences Information (BIREME)/Latin American and Caribbean Literature in Health Sciences (LILACS) - Virtual Health Library ( http://lilacs.bvsalud. org/); and PubMed - US National Library of Medicine, National Institutes of Health (https://www.ncbi.nlm.nih.gov/pubmed). Finally, when the search was negative for the authors' names, an additional search was performed through the title of the work, in the same databases.

For studies that were published in journals, agreement with the work previously presented at the medical congress was evaluated. Changes in titles, authors, objectives, materials and methods, results and conclusions were examined.

The absolute number of publications, the year and publication journal (national or international), type of study and quality of scientific evidence were analyzed. The journals were classified according to the Qualis classification of journals of the Coordination for the Improvement of Higher Education Personnel (CAPES), for the 4-year period 2013-2016 ${ }^{14}$. The score in the Medicine II category was considered through the standardization of the Postgraduate Program in Health Sciences at the Federal University of Goiás. The publication rate for each congress was obtained from the proportion of works presented that were published.

To classify the degree of scientific evidence, the classification validated by the Brazilian Medical Association was used: (a): experimental or observational studies of better consistency (meta-analyses or randomized clinical trials); (b): less consistent experimental or observational studies (other non-randomized clinical trials or observational studies or case-control studies); (c): reports or case series (uncontrolled studies); (D): opinion without critical evaluation, based on consensus, physiological studies or animal models. ${ }^{15}$.

\section{Statistical analysis}

The collected data were initially entered in a spreadsheet using the Microsoft Office Excel program version 2013, (Microsoft Corporation, Redmond, CA, USA), and later analyzed with the aid of the statistical program Statistical Package for the Social Sciences (SPSS) version 26.0 (IBM Corporation, Armonk, NY, USA). The data were characterized by means of absolute frequency (n) and relative frequency (\%). In this study, non-parametric statistical tests and techniques were applied, as verified through the Kolmogorov-Smirnov normality test. The comparison of the 
dynamics of scientific production between the groups was performed using Pearson's $\chi^{2}$ test followed by post hoc analysis ${ }^{16}$. Among the articles published from each congress, the comparison of the journal's impact factor was made done using the Kruskal-Wallis test. In all analyses, the level of significance was $5 \%(\mathrm{p}<0.05)$.

\section{Ethics aspects}

According to what was established in the Resolution of the National Health Council (CNS) No. 466, of December 12, 2012, it was not necessary to submit this study to the National Research Ethics Commission (CEP/CONEP), as it involved free data with unrestricted access ${ }^{17}$. The information obtained was extracted from secondary banks, in the public domain. Thus, an informed consent term was not needed, nor was there any identification of the research subjects.

\section{RESULTS}

The study included 266 abstracts of scientific studies presented at the three selected events in 2017. Most of them were conducted predominantly in public institutions $(71.1 \%)$ and presented in the form of a poster (77.8\%). The prevalent themes were breast surgery $(19.2 \%)$ and histological aspects (19.5\%) (Table 1).

Table 1. Characterization of institution of origin, type of presentation and theme of the works presented at three mastology congresses in Brazil, in 2017 ( $n=266)$.

\begin{tabular}{l|c|c}
\multicolumn{2}{l|}{} & N \\
Congress & 97 & 36.5 \\
\hline BBCS & 111 & 41.7 \\
\hline CBM & 58 & 21.8 \\
\hline JPM & 22 & 8.3 \\
\hline Type of institution & 55 & 20.7 \\
\hline Mixed & 189 & 71.1 \\
\hline Private &
\end{tabular}

FU of institution

\begin{tabular}{c|c|c}
\hline DF & 8 & 3.0 \\
\hline GO & 58 & 21.8 \\
\hline MG & 12 & 4.5 \\
\hline PE & 29 & 10.9 \\
\hline RN & 7 & 2.6 \\
\hline RS & 18 & 6.8 \\
\hline
\end{tabular}

Table 1. Continuation.

\begin{tabular}{l|c|c}
\multicolumn{1}{l|}{} & N & $\%$ \\
SP & 81 & 30.5 \\
\hline Others & 53 & 19.9 \\
\hline \multicolumn{2}{|l}{} \\
\hline Type of presentation & 19 & 7.1 \\
\hline Oral presentation & 207 & 77.8 \\
\hline Commer & 40 & 15.1 \\
\hline
\end{tabular}

Theme

\begin{tabular}{l|c|c}
\hline Basic sciences & 19 & 7.1 \\
\hline Surgery & 51 & 19.2 \\
\hline Epidemiology & 31 & 11.7 \\
\hline Histology & 52 & 19.5 \\
\hline Radiology & 17 & 6.4 \\
\hline Radiotherapy & 4 & 1.5 \\
\hline Rehabilitation & 11 & 4.1 \\
\hline Systemic treatment & 13 & 4.9 \\
\hline Others & 68 & 25.6 \\
\hline
\end{tabular}

Publication

\begin{tabular}{c|c|c}
\hline No & 245 & 92.1 \\
\hline Yes & 21 & 7.9 \\
\hline Quality of journal
\end{tabular}

\begin{tabular}{c|c|c}
\hline A1 & 1 & 4.8 \\
\hline A2 & 3 & 14.3 \\
\hline B1 & 6 & 28.6 \\
\hline B2 & 2 & 9.5 \\
\hline B4 & 1 & 4.8 \\
\hline B5 & 8 & 38.1 \\
\hline
\end{tabular}

Year of publication

\begin{tabular}{l|l|l}
\hline 2017 & 4 & 19.0 \\
\hline 2018 & 9 & 42.9 \\
\hline 2019 & 8 & 38.1 \\
\hline Concordance
\end{tabular}

\begin{tabular}{l|c|c}
\hline Partial & 13 & 61.9 \\
\hline Total & 8 & 38.1 \\
\hline
\end{tabular}

Degree of recommendation

\begin{tabular}{c|c|c}
\hline B & 15 & 71.4 \\
\hline C & 1 & 4.8 \\
\hline D & 5 & 23.8 \\
\hline
\end{tabular}

n: absolute frequency; \%: relative frequency; BBCS: Brazilian Breast Cancer Symposium; CBM: Brazilian Congress of Mastology; JPM: Jornada Paulista de Mastologia; FU: federation unit 
Considering the origin of the works presented, there was a predominance of studies conducted in the same state in which the event was held (Table 2).

Among all the abstracts presented, 21 (7.9\%) were published in an indexed journal. All articles were published in English and most of these publications occurred in journals classified

Table 2. Comparison of institution of origin, type of presentation and theme of works between the three congresses analyzed $(n=266)$.

\begin{tabular}{|c|c|c|c|c|}
\hline & \multicolumn{3}{|c|}{ Congress, n (\%) } & \multirow{2}{*}{$p^{*}$} \\
\hline & BBCS & CBM & JPM & \\
\hline \multicolumn{5}{|c|}{ Type of institution } \\
\hline Mixed & $9(9.3)$ & $10(9.0)$ & $3(5.2)$ & \multirow{3}{*}{0.01} \\
\hline Private & $13(13.4)$ & $25(22.5)$ & $17(29.3) \dagger$ & \\
\hline Public & $75(77.3)$ & $76(68.5)$ & $38(65.5)$ & \\
\hline \multicolumn{5}{|c|}{ FU of institution } \\
\hline DF & $7(7.2) \dagger$ & $0(0.0)$ & $1(1.7)$ & \multirow{8}{*}{$<0.001$} \\
\hline GO & $54(55.7) \dagger$ & $4(3.6)$ & $0(0.0)$ & \\
\hline MG & $2(2.1)$ & $8(7.2)$ & $2(3.4)$ & \\
\hline PE & $3(3.1)$ & $26(23.4) \dagger$ & $0(0.0)$ & \\
\hline $\mathrm{RN}$ & $0(0.0)$ & $4(3.6)$ & $3(5.2)$ & \\
\hline RS & $2(2.1)$ & $12(10.8)$ & $4(6.9)$ & \\
\hline SP & $14(14.4)$ & $24(21.6)$ & $43(74.1) \dagger$ & \\
\hline Others & $15(15.5)$ & $33(29.7) \dagger$ & $5(8.6)$ & \\
\hline
\end{tabular}

Type of presentation

\begin{tabular}{|c|c|c|c|c|}
\hline $\begin{array}{l}\text { Oral } \\
\text { presentation }\end{array}$ & $15(15.5)$ & $10(9.0)$ & $4(6.9)$ & \\
\hline Poster & $67(69.1)$ & $76(68.5)$ & 54 (93.1) & 0.06 \\
\hline $\begin{array}{l}\text { Comment } \\
\text { poster }\end{array}$ & $15(15.5)$ & $25(22.5)$ & $0(0.0)$ & \\
\hline
\end{tabular}

Theme

\begin{tabular}{|c|c|c|c|c|}
\hline Basic sciences & $16(16.5) \dagger$ & $3(2.7)$ & $0(0.0)$ & \multirow{9}{*}{0.005} \\
\hline Surgery & $11(11.3)$ & $28(25.2) \dagger$ & $12(20.7)$ & \\
\hline Epidemiology & $14(14.4)$ & $12(10.8)$ & $5(8.6)$ & \\
\hline Histology & 18 (18.6) & $23(20.7)$ & $11(19.0)$ & \\
\hline Radiology & $5(5.2)$ & $6(5.4)$ & $6(10.3)$ & \\
\hline Radiotherapy & $2(2.1)$ & $1(0.9)$ & $1(1.7)$ & \\
\hline Rehabilitation & $4(4.1)$ & $7(6.3)$ & $0(0.0)$ & \\
\hline $\begin{array}{l}\text { Systemic } \\
\text { treatment }\end{array}$ & $5(5.2)$ & $4(3.6)$ & $4(6.9)$ & \\
\hline Others & $22(22.7)$ & $27(24.3)$ & $19(32.8)$ & \\
\hline \multicolumn{5}{|l|}{ Publication } \\
\hline No & $84(86.6)$ & 105 (94.6) & $56(96.6)$ & \multirow{2}{*}{0.03} \\
\hline Yes & $13(13.4) \dagger$ & $6(5.4)$ & $2(3.4)$ & \\
\hline
\end{tabular}

*Pearson $\chi^{2}$ test; $+\chi^{2}$ post hoc test; $n$ : absolute frequency; \%: relative frequency; BBCS: Brazilian Breast Cancer Symposium; CBM: Brazilian Congress of Mastology; JPM: Jornada Paulista de Mastologia; FU: federation unit. as Qualis B5 $(\mathrm{n}=8 ; 38.1 \%)$. Considering the agreement between the abstract presented at the congress and the abstract of the published article, it was observed that 13 (61.9\%) showed some modification (Table 1).

In 2017, the publication rate for the BBCS, CBM and JPM was $13.4,5.4$ and $3.4 \%$, respectively $(\mathrm{p}=0.03)$. In the comparison between congresses, there was a higher rate of studies from private institutions at JPM, and surgical studies at CBM (Table 2). Table 3 shows the profile of the articles published from each selected congress.

Considering the published articles, there was no difference in journal impact factor between the congresses at which the work was initially presented ( $p=0.49$; Figure 1). Table 4 shows the nominal distribution of journals in which the works were published, with no difference between congresses $(p=0.54)$. Nominally, the journal Mastology, organized by the Brazilian Society of Mastology (SBM), was the journal that received the largest number of publications $(n=8 ; 38.1 \%$; Figure 2). Analyzing the frequency of publications between the groups according to the type of institution, it was observed that the papers published from the BBCS and CBM were mainly from public institutions (Table 5).

Table 3. Comparison of articles published from three mastology congresses that took place in Brazil in 2017 ( $n=21)$.

\begin{tabular}{|c|c|c|c|c|}
\hline & \multicolumn{3}{|c|}{ Congress, n (\%) } & \multirow{2}{*}{$\mathrm{p}$} \\
\hline & BBCS & CBM & JPM & \\
\hline \multicolumn{5}{|c|}{ Type of journal } \\
\hline A1 & $1(7.7)$ & $0(0.0)$ & $0(0.0)$ & \multirow{6}{*}{0.98} \\
\hline A2 & $2(15.4)$ & $1(16.7)$ & $0(0.0)$ & \\
\hline B1 & $3(23.1)$ & $2(33.3)$ & $1(50.0)$ & \\
\hline B2 & $1(7.7)$ & $1(16.7)$ & $0(0.0)$ & \\
\hline B4 & $1(7.7)$ & $0(0.0)$ & $0(0.0)$ & \\
\hline B5 & $5(38.5)$ & $2(33.3)$ & $1(50.0)$ & \\
\hline \multicolumn{5}{|c|}{ Year of publication } \\
\hline 2017 & $3(23.1)$ & $1(16.7)$ & $0(0.0)$ & \multirow{3}{*}{0.88} \\
\hline 2018 & $6(46.2)$ & $2(33.3)$ & $1(50.0)$ & \\
\hline 2029 & $4(30.8)$ & $3(50.0)$ & $1(50.0)$ & \\
\hline \multicolumn{5}{|c|}{ Concordance } \\
\hline Partial & $9(69.2)$ & $4(66.7)$ & $0(0.0)$ & \multirow{2}{*}{0.16} \\
\hline Total & $4(30.8)$ & $2(33.3)$ & $2(100.0)$ & \\
\hline \multicolumn{5}{|c|}{ Degree of recommendation } \\
\hline B & $9(69.2)$ & $5(83.3)$ & $1(50.0)$ & \multirow{3}{*}{0.03} \\
\hline c & $0(0.0)$ & $0(0.0)$ & $1(50.0) \dagger$ & \\
\hline D & $4(30.8)$ & $1(16.7)$ & $0(0.0)$ & \\
\hline
\end{tabular}

*Pearson $\chi^{2}$ test; $+\chi^{2}$ post hoc test; $n$ : absolute frequency; \%: relative frequency; BBCS: Brazilian Breast Cancer Symposium; CBM: Brazilian Congress of Mastology; JPM: Jornada Paulista de Mastologia. 


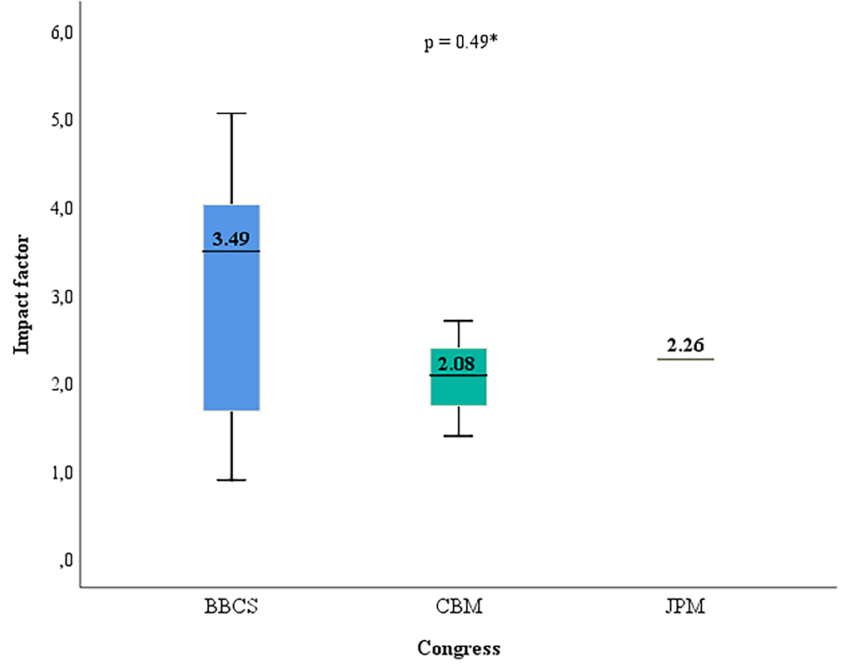

*Kruskal-Wallis test (comparison between two medians, because only one article from the Jornada Paulista de Mastologia (JPM) was published in a journal with an available impact factor); BBCS: Brazilian Breast Cancer Symposium; CBM: Brazilian Congress of Mastology.

Figure 1. Boxplot comparing the impact factor of the journals between groups $(n=21)$.

Table 4. Comparison of journal in which the article was published between the groups $(n=21)$.

\begin{tabular}{|c|c|c|c|c|}
\hline \multirow{2}{*}{ Journal } & \multicolumn{3}{|c|}{ Congress, n (\%) } & \multirow{2}{*}{$\mathbf{p}^{*}$} \\
\hline & BBCS & CBM & JPM & \\
\hline $\begin{array}{l}\text { Aesthetic Plastic } \\
\text { Surgery }\end{array}$ & $0(0.0)$ & $1(16.7)$ & $0(0.0)$ & \multirow{13}{*}{0.54} \\
\hline $\begin{array}{l}\text { Biointerface Research } \\
\text { in Applied Chemistry }\end{array}$ & $1(7.7)$ & $0(0.0)$ & $0(0.0)$ & \\
\hline Breast (Edinburgh) & $1(7.7)$ & $0(0.0)$ & $0(0.0)$ & \\
\hline Breast Care & $0(0.0)$ & $1(16.7)$ & $0(0.0)$ & \\
\hline Climacteric & $0(0.0)$ & $0(0.0)$ & $1(50.0)$ & \\
\hline Clinical Breast Cancer & $0(0.0)$ & $1(16.7)$ & $0(0.0)$ & \\
\hline $\begin{array}{l}\text { Food Research } \\
\text { International }\end{array}$ & $1(7.7)$ & $0(0.0)$ & $0(0.0)$ & \\
\hline $\begin{array}{l}\text { International Journal } \\
\text { of Nanomedicine }\end{array}$ & $1(7.7)$ & $0(0.0)$ & $0(0.0)$ & \\
\hline $\begin{array}{l}\text { Journal of Biomedical } \\
\text { Nanotechnology }\end{array}$ & $1(7.7)$ & $0(0.0)$ & $0(0.0)$ & \\
\hline $\begin{array}{l}\text { Journal of } \\
\text { Radiological } \\
\text { Protection }\end{array}$ & $1(7.7)$ & $0(0.0)$ & $0(0.0)$ & \\
\hline Mastology & $5(38.5)$ & $2(33.3)$ & $1(50.0)$ & \\
\hline MicroRNA & $0(0.0)$ & $1(16.7)$ & $0(0.0)$ & \\
\hline The Breast & $2(15.4)$ & $0(0.0)$ & $0(0.0)$ & \\
\hline
\end{tabular}

*Pearson $\chi^{2}$ test; n: absolute frequency; \%: realative frequency; BBCS:

Brazilian Breast Cancer Symposium; CBM: Brazilian Congress of Mastology; JPM: Jornada Paulista de Mastologia.

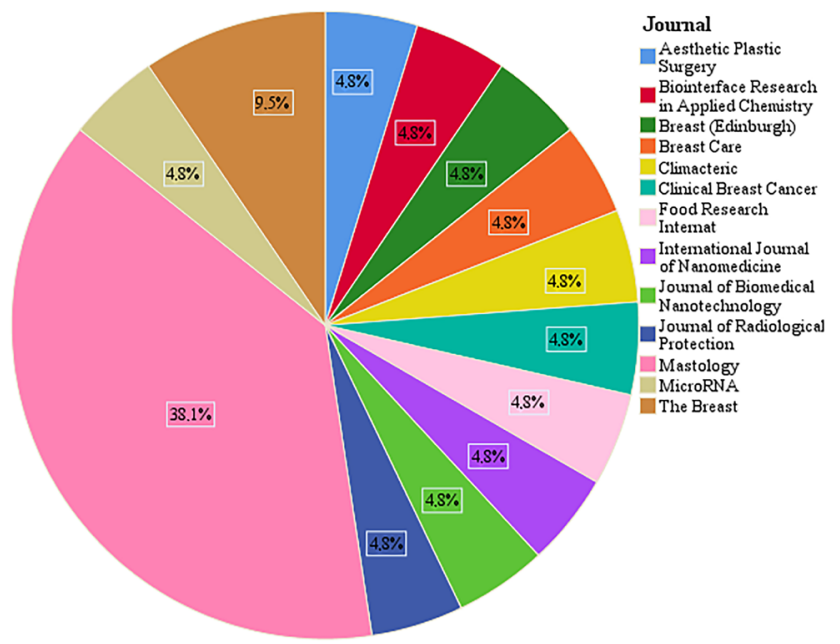

Figure 2. Pie chart describing the journals in which the articles were published $(n=21)$.

Table 5. Comparison of frequency of publications between groups according to type of institution.

\begin{tabular}{l|c|c|c|c}
\multirow{2}{*}{} & \multicolumn{3}{c|}{ Congress, $\mathrm{n}(\%)$} & \multirow{2}{*}{ P* } \\
\cline { 2 - 4 } \multicolumn{2}{c}{ Type of institution } & CBM & JPM & \\
\hline Mixed & $0(0.0)$ & $0(0.0)$ & $1(33.3) \dagger$ & $\mathbf{0 . 0 3}$ \\
\hline Private & $1(7.7)$ & $0(0.0)$ & $0(0.0)$ & 0.11 \\
\hline Public & $12(16.0) \dagger$ & $6(7.9)$ & $1(2.6)$ & $\mathbf{0 . 0 4}$ \\
\hline
\end{tabular}

* Pearson $\chi^{2}$ test; $\dagger \chi^{2}$ post hoc test; $n$ : absolute frequency; $\%$ : relative frequency; BBCS: Brazilian Breast Cancer Symposium; CBM: Brazilian Congress of Mastology; JPM: Jornada Paulista de Mastologia.

\section{DISCUSSION}

In Brazil, the first bibliometric studies related to mastology and breast cancer were published in the last decade, but they are restricted to surgical themes and breast reconstruction ${ }^{9,10}$. In other specialties, the content and publication rate of the main scientific congresses have been monitored over time and are indicators related to the production and dissemination of scientific knowledge $e^{6,718}$. In this context, the current study reveals the critical situation with publication rate of the main scientific events that address breast cancer in Brazil, in addition to providing an overview of the respective congresses.

The characterization of the works presented at the selected events revealed significant geographical differences in their origin, with a predominance of studies conducted in the state where the event was held. This finding goes against the current aims of universalization and decentralization of scientific knowledge, effected, in part, by holding meetings of this nature outside the Rio de Janeiro-São Paulo axis. In the coming years, greater access 
to communication technologies and the advancement of teleconferencing systems may further facilitate the dissemination of scientific knowledge by Brazilian researchers.

The publication rate observed in the three congresses, together, was only 7.9\%. This index is in line with that observed in most other specialty congresses conducted in Brazil, which generally varies between 5 and $20 \%^{6,718}$. In the international context, we did not identify in the literature other studies that analyzed events related to breast cancer, only some specific thematic assessments ${ }^{19}$. However, considering other international congresses on medical specialties, there are publication rates of scientific papers close to $50 \%$, reflecting a major gap in the capacity for scientific dissemination between the two contexts ${ }^{20,21}$.

Among the possible factors related to the low publication rate, the methodological limitations of the research presented in Brazilian scientific events should be highlighted ${ }^{13,22}$. These deficiencies end up being perpetuated in the respective scientific publications, and some reviews indicate that up to $75 \%$ of the articles published in certain journals have some flaw in the statistical analysis ${ }^{23}$. In the current study, this could be associated with the predominance of presentations in poster format, which generally correspond to studies with less scientific impact, and the predominance of publications in journals classified as Qualis B5, the lowest category among indexed journals. Although this information did not necessarily mean poor scientific quality, it could indicate methodological limitations that culminated in publications in a journal with a lower impact factor.

Other factors such as financial limitations, lack of institutional incentives and lack of technical support can also discourage the scientific publication of a recently completed study. However, in recent years, public policies to encourage research have culminated in a substantial increase in the number of published articles $^{4,13,24,25}$. This growth trend was also observed in the Brazilian participation in international events and research related to breast cancer $^{26}$. In this context, the expansion of existing incentives and the formulation of new strategies for the dissemination of scientific production should be considered fundamental pillars of government policies for science and technology. Nevertheless, the search for self-sustainable scientific projects and alternative sources of financial and structural resources represent another viable path for Brazilian researchers ${ }^{26,27}$.

Another point to be highlighted are inconsistencies between the presentation at the congress and the respective publication in about $60 \%$ of cases $^{28,29}$. This percentage is in line with that observed in other bibliometric studies and can be explained by several factors, such as the consolidation of data initially presented as preliminary results and the textual modifications suggested in the congress itself or by the journal's reviewers. On this issue, a study conducted by the Association of Surgeons of Great Britain and Ireland observed significant changes in the titles of the papers (8.8\%) and in the authors (58.5\%), increase or decrease in the sample (56\%), methodological changes $(21.1 \%)$ and different interpretation of results $(11.6 \%)^{28}$. Thus, the presentation and discussion of free themes at scientific events remain relevant in the process of building and disseminating knowledge.

In Brazil, the evaluation of scientific papers that will be accepted for presentation at a medical congress is the responsibility of the institution that organized the event. Generally, a specific committee is selected for this purpose, formed by professionals with recognized scientific experience. However, the criteria to be used by each professional, or in each congress, can vary and even be subjective. In some situations, duplicate, incomplete, inconclusive and/or serious methodological limitations are observed ${ }^{30}$. In addition, clinical case reports are presented without any relevant discussion or addition to the medical knowledge already available ${ }^{30,31}$. In addition, as the presenter of the free topic also needs to register for the event, there is the fear that the refusal of the submitted papers may reduce the final number of participants. Therefore, the data presented here may indicate the need for improvement and professionalization of this selection process, prioritizing technical and scientific criteria at the detriment of indiscriminate approval of free topics.

The current model of scientific production in Brazil is predominantly linked to graduate programs and financed by the authors themselves or by public institutions that support research ${ }^{24,25}$. Thus, the publication process becomes dependent on financial and motivational factors of the respective students and professors, who often give up publishing their works after rejection by the first journals. Accordingly, the predominance of articles published in the journal Mastology is possibly justified by a series of benefits for the publication of national articles ${ }^{32}$. This fact also reflects the relevance of class societies in the academic scenario of Brazil, considering that continuing education, research activities and the dissemination of scientific knowledge are present in the mission, vision and values of $\mathrm{SBM}^{33}$.

Among the congresses included in the present analysis, the BBCS organization format should be noted, where its presentation of free themes is included in the main program of the event and offers researchers a major role in the dissemination and discussion of their results ${ }^{12}$. On the other hand, CBM and JPM are congresses predominantly aimed at continuing education, whose presentation of free themes constitutes a secondary and discreet schedule ${ }^{11}$. This characteristic of encouraging researchers at the BBCS likely contributed to obtaining a higher publication rate, which was 2.5 times higher compared to CBM and 3.9 times higher compared to JPM. In addition, considering the impact factor of the journals in which the articles were published, it was observed that the average of the works previously presented at the BBCS was 3.49 compared to 2.08 at the CBM. This difference 
was not significant in the statistical analysis, probably due to the sample size, but possibly indicated a trend towards publications with a higher level of evidence.

The current study has limitations inherent to secondarybased investigations, such as retrospective design and limited access to some variables that could add information to the discussion. On the other hand, the standardization of the methodology and the rigor in the search for articles adds robustness to the data found in the present series, which is the first bibliometric survey in mastology in Brazil. The two-year period after the last event included minimizes the temporal bias that could be pointed out in relation to the publication rate, although this rate may, in fact, increase in the coming years. Finally, we suggest the continued evaluation of the publication of these meeting presentations over the next few years, to monitor the evolution of the publication rate of works presented at mastology congresses in Brazil.

\section{CONCLUSION}

In 2017 , less than $10 \%$ of the papers presented at breast cancer congresses held in Brazil were published in an indexed journal. Among the main specialty events in the country, the BBCS has a significantly higher publication rate.

\section{AUTHORS' CONTRIBUTIONS}

R.M.S.R.: Conceptualization, investigation, methodology, investigation, project administration, supervision, validation, visualization, writing - review \& editing.

S.N.: Conceptualization, investigation, validation, visualization, writing - original draft.

L.R.S.: Conceptualization, investigation, data curation, formal analysis, investigation, writing - original draft.

R.F: Data curation, formal analysis, investigation, writing review \& editing.

\section{REFERENCES}

1. Sarkar B, Wang YX, Cai J. The open access financial model hinders the growth of medical physics research in low-and middle-income countries. Med Phys. 2020. http://doi.org/10.1002/mp.14220

2. Guimarães J. Medical and biomedical research in Brazil. A comparison of Brazilian and international scientific performance. Ciênc Saúde Coletiva. 2004;9(2):307-27. https:// doi.org/10.1590/S1413-81232004000200009

3. Ejnisman L, Gomes GS, Oliveira RG, Malavolta EA, Gobbi RG, Camargo OP. Publication rates of papers presented at the BrazilianOrthopedicMeeting.ActaOrtopBras.2013;21(5):285-7. https://doi.org/10.1590/S1413-78522013000500009

4. Arap MA, Reis RB, Torricelli FC, Masson AL, Saad ED. Brazilian abstracts presented at the American Urological Association annual meetings: contribution, publication rates, and comparison with oncology abstracts. Int Braz J Urol. 2014;40(6):730-7. https:// doi.org/10.1590/S1677-5538.IBJU.2014.06.03

5. Albuquerque UP. A qualidade das publicações científicas - considerações de um editor de área ao final do mandato. Acta Bot Bras. 2009;23(1):292-6. https://doi.org/10.1590/S010233062009000100031

6. Forlin E, Fedato RA, Altmann-Junior W. Publication of studies presented as free papers at a Brazilian national orthopedics meeting. Rev Bras Ortop. 2013;48(3):216-20. https://doi. org/10.1016/j.rbo.2012.10.005

7. Yoshida BW, Holmo NF, Corregliano GT, Baldon KM, Souza e Silva N. Publicações indexadas geradas a partir de resumos de congressos de angiologia e cirurgia vascular no Brasil. J Vasc Bras. 2008;7(4):293-7. https://doi.org/10.1590/S167754492008000400002

8. Younes RN, Deheinzelin D, Birolini D. Graduate education at the faculty of medicine of the University of Sao Paulo: quo vadis? Clinics. 2005;60(1):6-8. http://doi.org/10.1590/S180759322005000100003

9. Pires DM, Mendonça ACG, Valadares CN, Barbosa GEF, Silva VB, Nunes AMS. Scientific publications of Brazilian mastologists regarding oncoplastic and reconstructive breast surgery: a bibliometric study. Mastology. 2017;27(2):124-30. http://doi.org/10.5327/Z2594539420170000177

10. Freitas-Junior R, Faria SS, Paulinelli RR, Ferreira NC. Bibliometrics trends in oncoplastic surgery and breast reconstruction from 1980 to 2016. Eur J Cancer. 2018;92(Suppl. 3):S87. http://doi.org/10.1016/S0959-8049(18)30488-X

11. Jornada Paulista de Mastologia. Programação [Internet]. [cited on May 17, 2020]. Available at: http://jornada.spmastologia. com.br/jpm-2020

12. Brazilian Breast Cancer Symposium. Program [Internet]. [cited on May 12, 2020]. Available at: https://2020.bbcs.org.br/ program/

13. Pinheiro CMA, Masson ALS, Faingezicht AM, Borghesi G, Rotea-Junior W, Prisco FE, et al. Estudos Brasileiros Apresentados nos Encontros Anuais da ASCO entre 2001 e 2007: Aumento de Produção, com Baixa Taxa de Publicação. Rev Bras Cancerol. 2009;55(3):221-7.

14. Comissão de Aperfeiçoamento de Pessoal de Ensino Superior. Plataforma Sucupira. Webqualis Capes [Internet]. [cited on May 2, 2020]. Available at: https://sucupira.capes.gov.br/ sucupira/public/consultas/coleta/veiculoPublicacaoQualis/ listaConsultaGeralPeriodicos.jsf

15. Associação Médica Brasileira e Conselho Federal de Medicina. Projeto Diretrizes [Internet]. [cited on Jan. 2, 2020]. Available at: http://www.portalmedico.org.br/diretrizes/100_diretrizes/ Texto_Introdutorio.pdf 
16. MacDonald PL, Gardner RC. Type I error rate comparisons of posthoc procedures for Ij Chi-Squaretables.EducPsycholMeas. 2000;60(5):735-754. http://doi.org/10.1177/00131640021970871

17. Brasil. Ministério da Saúde. Conselho Nacional de Saúde. Resolução $n^{\circ}$ 466, de 12 de dezembro de 2012. Aprova as diretrizes e normas regulamentadoras de pesquisas envolvendo seres humanos. Diário Oficial da União. 2013;(12 Seção 1):59.

18. Andrade VA, Carpini S, Schwingel R, Calderan TR, Fraga GP. Publication of papers presented in a Brazilian Trauma Congress. Rev Col Bras Cir. 2011;38(3):172-6. https://doi. org/10.1590/S0100-69912011000300006

19. Mokbel K. The Twenty-third Annual San Antonio Breast Cancer Symposium. Curr Med Res Opin. 2001;16(4):276-84. https://doi.org/10.1185/030079901750120213

20. Meissner A, Delouya G, Marcovitch D, Donath D, Taussky D. Publication rates of abstracts presented at the 2007 and 2010 Canadian Association of Radiation Oncology meetings. Curr Oncol. 2014;21(2):e250-4. https://doi.org/10.3747\%2Fco.21.1764

21. Ohtori S, Orita S, Eguchi Y, Aoki Y, Suzuki M, Kubota G, et al. Oral Presentations Have a Significantly Higher Publication Rate, But Not Impact Factors, Than Poster Presentations at the International Society for Study of Lumbar Spine meeting: Review of 1126 Abstracts From 2010 to 2012 Meetings. Spine (Phila Pa 1976). 2018;43(19):1347-54. https://doi.org/10.1097/ BRS.0000000000002620

22. Santos EF, Pereira MG. Qualidade dos resumos estruturados apresentados em congresso médico. Rev Assoc Med Bras. 2007;53(4):355-9. https://doi.org/10.1590/S010442302007000400023

23. Bertoldo JG, Coimbra JLM, Guidolin AF, Miqueloto A, Toaldo D. Uso ou abuso em testes de comparações de média: conhecimento científico ou empírico? Ciência Rural. 2008;38(4):1145-8. https:// doi.org/10.1590/S0103-84782008000400039

24. Zorzetto R, Razzouk D, Dubugras MT, Gerolin J, Schor N, Guimarães JA, et al. The scientific production in health and biological sciences of the top 20 Brazilian universities. Braz J Med Biol Res. 2006;39(12):1513-20. https://doi.org/10.1590/ S0100-879X2006005000040

25. Cardoso SC, Gattás GJF. The scientific production of full professors of the Faculdade de Medicina da Universidade de São Paulo:aview of the period of 2001-2006. Clinics. 2009;64(9):903-9. https://doi.org/10.1590/S1807-59322009000900012

26. Freitas PF, Freitas-Junior RF, Soares LR, Santos FC, Nazário ACP. Série temporal da apresentação de trabalhos brasileiros no San Antonio Breast Cancer Symposium. Rev Bras Mastologia. 2014;24(1):4-8. https://doi.org/10.5327/Z201400010002RBM

27. Kotiranta A, Tahvanainen A, Kovalainen A, Poutanen S. Forms and varieties of research and industry collaboration across disciplines. Heliyon. 2020;6(3):e03404. https://doi. org/10.1016/j.heliyon.2020.e03404

28. Balasubramanian SP, Kumar ID, Wyld L, Reed MW. Publication of surgical abstracts in full text: a retrospective cohort study. Ann R Coll Surg Engl. 2006;88(1):57-61. https:// doi.org/10.1308/003588406x82961

29. Kinsella SD, Menge TJ, Anderson AF, Spindler KP. Publication rates of podium versus poster presentations at the American Orthopaedic Society for Sports Medicine meetings: 20062010. Am J Sports Med. 2015;43(5):1255-9. https://doi. org/10.1177/0363546515573939

30. XXIX Encontro Científico dos Acadêmicos de Medicina e VII Congresso Goiano de Ética Médica. Rev Patol Trop. 2017;46(2 Suppl. 2):1-166. https://doi.org/10.5216/rpt.v46i2.49414

31. $57^{\circ}$ Congresso Brasileiro de Ginecologia e Obstetrícia. Temas Livres aprovados e apresentados. Femina. 2017;45(Spec. Ed.):1-148.

32. Mastology [Internet]. [cited on May 17, 2020]. Available at: https://www.mastology.org/

33. Sociedade Brasileira de Mastologia. Sobre nós [Internet]. [cited on May 12, 2018]. Available at: http://www.sbmastologia.com. br/o-que-e-sbm/ 